\title{
HOW TO APPLY THE NUMBERED HEAD TOGETHER LEARNING MODEL TO IMPROVE INDONESIAN LEARNING OUTCOMES IN FIRST MIDDLE SCHOOL
}

\author{
Firman $^{1^{*}}$ \\ Mirnawati ${ }^{2}$ \\ Hisbullah $^{3}$ \\ $\mathrm{Usman}^{4}$ \\ Muhammad Affan Ramadhana ${ }^{5}$ \\ Erwin Harianto ${ }^{6}$ \\ 1,2,3IAIN Palopo, Palopo Indonesia \\ ${ }^{4}$ Universitas Negeri Makassar, Makassar, Indonesia \\ ${ }^{5}$ ATI Dewantara Palopo, Palopo, Indonesia \\ ${ }^{6}$ IAI Al Amanah Jeneponto, Jeneponto, Indonesia \\ firman_999@iainpalopo.ac.id ${ }^{\left.1^{*}\right)}$ \\ affan@pustaka.my.id ${ }^{5}$
}

\begin{abstract}
This research is a classroom action research that aims to determine whether the cooperative learning Numbered Head Together (NHT) can improve students' learning outcome in Indonesian course. The subjects of this study were 45 students of class VII A of SMP Negeri 8 Palopo in the even semester of the 2018/2019 academic year. This research was carried out in two cycles, and each cycle consists of six meetings. Data collection was carried out using learning outcomes tests and observations. The data collected were analyzed using quantitative analysis, and the observation data were analyzed using qualitative analysis. The results showed that the average score of students in the first cycle was 40.02, with a standard deviation of 20.21. while in the second cycle, the average score was 68.26 , with a standard deviation of 12.00. It shows that classical student learning outcomes have been achieved. From the results of this study, it can be concluded that with the implementation of cooperative learning NHT in the learning process, the learning outcomes, attendance, readiness, and activeness of students can increase.
\end{abstract}

Keywords: learning outcomes; cooperative learning; numbered head together

Published by:

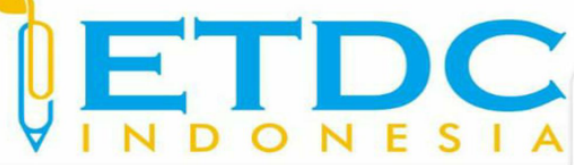

Copyright (C) 2021 The Author (s)

This article is licensed under CC BY 4.0 License

$(c c)$ BY 


\section{HOW TO APPLY THE NUMBERED HEAD TOGETHER LEARNING MODEL TO IMPROVE INDONESIAN LEARNING OUTCOMES IN FIRST MIDDLE SCHOOL}

\section{Introduction}

One of the things that play an important role in teaching is the process of implementing teaching. Exemplary teaching implementation is strongly influenced by good planning (Budiani et al., 2017). Teaching is based on the interaction between two different things but forming a single unit, like a coin that contains two (Syamsuddin, 2019). Learning is an activity carried out by students, while teaching is an activity carried out by teachers.

Teaching activities carried out by teachers significantly affect student learning activities. To implement teaching efficiently and effectively, systematic planning is needed with a more meaningful teaching and learning process and activates students (Hisbullah, 2020). Similarly, in teaching Indonesian, the interaction between students and teachers must occur in dialogue. It is intended that teachers can motivate to generate student interest in carrying out Indonesian language learning activities (Mirnawati \& Firman, 2019). A teaching system that provides opportunities for students to work together in completing structured tasks is referred to as a "Gotong Royong" or "cooperative learning" system. In this case, the teacher acts as a facilitator.

Cooperative learning has successfully improved student learning outcomes because it can enable students to learn from friends (Sudarsana, 2018). Slavin also argues that cooperative learning creates conditions of mutual assistance for mutual success that are not found in studentsother lessons (Aji, 2019). It also appears in the results of research in developed countries which determine that cooperative learning can improve the academic achievement of both junior and senior high school students.

Cooperative learning begins by forming groups of students in a class. Teachers or students can do the formation of these groups. The members in a group should be varied. Cooperative learning techniques in a group should be varied. Cooperative learning techniques are oriented towards achieving the goals of each individual by contributing to the achievement of other individual goals. Their goals are achieved if and only if other students will otherwise achieve those goals. In contrast to cooperative learning, competitive learning is oriented towards the goals of each individual by making the frequency of achieving other individual goals.

To apply cooperative learning into the teaching and learning process, a teacher's expertise is needed in reconstructing collaborative skills and dealing with various problems that 
arise. Responsiveness and creativity, and a persuasive approach are necessary for a teacher to deal with this (Luhulima, 2021).

The classroom atmosphere needs to be planned and built so that students get the opportunity to interact with each other. In this interaction, students will form communication that allows them to love the learning process and respect each other (Sukirman \& Mirnawati, 2020). In a learning atmosphere full of competition, student isolation, negative attitudes, and relationships will act and turn off student enthusiasm; attitudes with negative relationships will form and turn off student enthusiasm. This atmosphere will inhibit the formation of student knowledge actively. Therefore, teachers need to create a learning atmosphere so that students work together in cooperation.

A classroom is an excellent place for cooperative learning activities. In the classroom, students can work in small groups to solve or solve a problem together. Cooperative learning will be able to train students to hear the opinions of others and summarize them. Cooperative learning in Indonesian will help students improve positive attitudes in Indonesian(Fatimah, 2016). Individual students build confidence in their ability to solve Indonesian language problems, thereby reducing or even eliminating the anxiety experienced by many students. Cooperative learning has also proven to be very beneficial for heterogeneous students. (Israel, 2019).

Cooperative learning includes a group of students who work as a team to solve a problem, complete a task or do something to achieve another common goal. Cooperative learning emphasizes peers who interact with each other to solve or discuss a problem or task(Sunarya, 2018).

Riger and David Johnson say that not all group work can be considered cooperative learning (Esminarto et al., 2016; Wahyuni, 2016). Five elements distinguish the cooperative learning model from group work, namely:

a. Positive interdependence. The success of the group lies in the efforts of each member.

b. Individual responsibility. If assignments with assessment patterns are made according to cooperative learning model procedures, each student will feel responsible for doing their best.

c. Stay face. Each group should be allowed to meet face to face and discuss.

d. Communication between members. This element requires that students be equipped with various communication skills.

e. Group process evaluation. Teachers need to schedule a particular time for groups to evaluate the group work process and the results of their collaboration to work together more 
effectively.

\section{Cooperative learning with Numbered Head Together (NHT) type}

Numbered-head-together (NHT) is an approach to involve more students in studying the material covered in a lesson by checking their understanding of the lesson's content (Yenni, 2016). The steps in cooperative learning type Numbered-Head-Together (Yanti et al., 2016) as follows :

\section{Step I}

Numbering. The teacher divides into groups of 3-5 people for each group member to be numbered between 1 to 5

\section{Step II}

Asking question. The teacher asks a question to the students. Questions may vary. Questions can be particular and in the form of interrogative sentences or the form of directions.

\section{Step III}

Think together. Students put together the answers to the questions and make sure each member on their team knows the answers.

\section{Step IV}

Answering, the teacher calls a certain number then students raise their hands and try to answer questions for the whole class.

\section{Method}

This research is class-based action research (Classroom Action Research). This research was conducted in class VII A of SMP Negeri 8 Palopo, with 45 students. This classroom action research is planned for two cycles. Each cycle is carried out according to the changes to be achieved. Cycle I is planned for three weeks with six meetings, and Cycle II is planned for three weeks and is also carried out with six meetings. Each cycle has stages of planning, implementation, observation, and reflection.

\section{Result}

This section discusses the research results showing an increase in Indonesian language learning outcomes for seventh-grade students of SMP Negeri 8 Palopo after NHT type cooperative learning is applied. As for what is analyzed is the score of student learning outcomes given at the end of each cycle descriptively and changes in student attitudes taken from recording observations and responses and reflections given by students' written and verbal comments. 


\section{a. Descriptive Analysis of Cycle I. Test Results}

In the first cycle, a test of learning outcomes was carried out in the form of a daily test after presenting the subject area of flat shapes for five meetings. The data on the score of learning outcomes in the first cycle can be seen in Table 1. below:

Table 1. Statistics of Student Learning Outcomes for Class VII Junior High School cycle 1

\begin{tabular}{cc}
\hline Statistics & Statistical value \\
\hline Total students & 45 \\
Ideal score & 100.00 \\
Maximum value & 88.00 \\
Minimum value & 11.00 \\
Score range & 77.00 \\
Average score & 40.02 \\
median & 37.66 \\
Mode & 30.00 \\
Standard deviation & 20.21 \\
\hline
\end{tabular}

Table 1 shows that the average score (mean) of Indonesian language learning outcomes after NHT type cooperative learning has been applied in the first cycle is 40.02 from the ideal that may be achieved is 100 . Grade VII SMP students in the first cycle were $40.02 \%$. This result is due to the lack of attention by doing other activities during the learning process.

If the student learning outcomes scores are grouped into five categories, the frequency distribution of scores is obtained as presented in table 3:

Table 2. Distribution of Frequency and Percentage of Indonesian Language Learning Outcomes Scores for Class VII Junior High School Students in Cycle I

\begin{tabular}{|c|c|c|c|}
\hline Score & Category & Frequency & Percentage $(\%)$ \\
\hline $0-34$ & very low & 22 & 48.9 \\
\hline $35-54$ & low & 12 & 26.7 \\
\hline $55-64$ & medium & 6 & 13.3 \\
\hline $65-84$ & high & 4 & 8.9 \\
\hline $85-100$ & very high & 1 & 2.2 \\
\hline \multicolumn{2}{|c|}{ amount } & 45 & 100 \\
\hline
\end{tabular}

Table 2 shows that the average score of seventh-grade students' learning outcomes after being given action in the first cycle is in the very low category. If the student learning outcomes in the first cycle are analyzed, then the percentage of student learning completeness in the first cycle can be seen in Table 3 below:

Table 3. Distribution of Learning Completeness for Class VII Junior High School Students in Cycle I

\begin{tabular}{cccc}
\hline Score & Category & Frequency & Percentage $(\%)$ \\
\hline $0 \%-64 \%$ & Not Complete & 40 & 88.89 \\
$6 \%-100 \%$ & Complete & 5 & 11.11 \\
\hline
\end{tabular}




\begin{tabular}{cccc}
\hline Score & Category & Frequency & Percentage (\%) \\
\hline & amount & 45 & 100 \\
\hline
\end{tabular}

Table 3 shows that the percentage of class completeness is $11.11 \%$, namely five students out of 45 are included in the complete category, and 88,895 or 40 students out of 45 are included in the incomplete category. It means that 40 students need improvement because they have not reached the individual completeness criteria.

\section{b. Descriptive Analysis of Cycle II Test Results}

It is the same only in the first cycle; the learning outcomes test in the second cycle with the subject of volume building is carried out in daily tests. The results of the descriptive analysis show that the average score achieved by grade VII SMP students who are taught using the NHTtype cooperative approach in cycle II is presented in Table 4, as follows:

Table 4. Statistics of Student Learning Outcomes for Class VII Junior High School Cycle II

\begin{tabular}{cc}
\hline Statistics & Statistical value \\
\hline Total students & 45 \\
Ideal score & 100 \\
Maximum value & 90.00 \\
Minimum value & 32.00 \\
Score range & 58.00 \\
Average score & 68.26 \\
median & 68.50 \\
Mode & 65.00 \\
Standard deviation & 12.00 \\
\hline
\end{tabular}

From the table above, the average score (mean) of Indonesian language learning outcomes for seventh-grade junior high school students after applying NHT type cooperative learning in cycle II is 68.26 , from the ideal score that may be achieved is 100 . Indonesian class VII junior high school students in the second cycle were $68.26 \%$. Even though there has been an increase in this cycle, there are still students who carry out other activities during the learning process.

Individually, the score achieved by students varies from a minimum score of 32 from the lowest possible score of 0 to a maximum score of 90 from the highest (ideal) score that may be achieved 100 with a score range of 58.00. It means that students' Indonesian learning outcomes vary from very low learning outcomes scores (32\%) to high learning outcomes scores $(58 \%)$.

If the scores of student learning outcomes are grouped into five categories, the frequency distribution of scores is obtained as in Table 5, as follows: 
Table 5. Distribution of Frequency and Percentage of Indonesian Language Learning Outcomes Scores for Class VII Junior High School Students in Cycle II

\begin{tabular}{|c|c|c|c|}
\hline Score & Category & Frequency & $(\%)$ \\
\hline $0-34$ & very low & 2 & 4.4 \\
\hline $35-54$ & low & 3 & 6.8 \\
\hline $55-64$ & medium & 0 & 0 \\
\hline $65-84$ & high & 38 & 84.4 \\
\hline $85-100$ & very high & 2 & 4.4 \\
\hline \multicolumn{2}{|c|}{ amount } & 45 & 100 \\
\hline
\end{tabular}

Table 5. shows that the average score of seventh-grade students' learning outcomes after being given action in cycle II is in the very high category. If student learning outcomes in cycle II are analyzed, then the percentage of student learning completeness in cycle II can be seen in Table 6 below:

Table 6. Distribution of Learning Completeness for Class VII Junior High School Students in Cycle II

\begin{tabular}{cccc}
\hline Score & Category & Frequency & Percentage \\
\hline $0 \%-64 \%$ & Not Complete & 5 & 11.11 \\
$6 \%-100 \%$ & Complete & 40 & 88.89 \\
\hline \multicolumn{2}{c}{ amount } & 45 & 100 \\
\hline
\end{tabular}

Table 6 shows that the percentage of class completeness is $88.89 \%$, namely 40 students out of 45 are included in the complete category, and $11.11 \%$ and five students out of 45 are included in the incomplete category.

\section{c. Changes in Student Attitudes}

During the study and an increase in Indonesian learning outcomes in cycle I and cycle II, several changes occurred in each student in learning Indonesian. These changes were obtained from the observation sheet at each meeting which was recorded in each cycle. The observation sheet is to find out changes in student attitudes during the teaching and learning process in the classroom.

The changes in student attitudes from each cycle are as follows:

1. The student's attention in the first cycle was still running as usual, such as students' lack of enthusiasm in completing LKS in groups. However, there was an increase in group worksheets between group members in the second cycle by providing mutual guidance to group members who did not understand the subject matter. It is due to the appreciation that motivates them to work together in completing LKS.

2. When students had discussions with their group members in cycle II, 8-10 students were doing other activities. While in cycle II, students who carry out activities only range from 


\section{3-5. person.}

3. In the first cycle, students' activities in the teaching and learning process, such as answering questions, asking about the material being discussed, as well as being good at working on questions still in the second cycle meeting, have dared to ask and scramble to raise their hands to answer from the teacher and go up to work on the blackboard questions without being appointed.

4. In the first cycle, the students presenting the discussion results were less severe and did not dare. Meanwhile, in the second cycle, the students looked brave and earnest in explaining the group discussions.

5. At the time of the percentage of discussion results, each group is allowed to respond to the results of other groups' discussions. In the first cycle, few groups responded to the results of other group discussions. On the other hand, in the second cycle, the students' enthusiasm increased, especially in providing responses and explanations.

\section{d. Reflection on the Implementation of Actions in the Indonesian Language Teaching and Learning Process}

\section{Reflection Cycle I}

Cycle I was held for six meetings by applying NHT cooperative learning with various models used in the teaching and learning process. In the first cycle, many students still did not attend the lesson; they did not attend without explanation or were sick. Students think that Indonesian language lessons are complicated with formulas and Indonesian language problems that are difficult to solve.

Before entering the subject matter, the teacher always conveys the learning objectives and then motivates students to be interested in the subject matter, but with that, there are still many students who ignore the teacher. So that in doing the LKS, you do not know how to finish.

At the end of each meeting, the teacher always gives homework (PR) with the aim that students want to learn and train themselves in solving existing questions and collect them at the next meeting. However, at the next meeting, many students did not finish the homework with the reasons they gave.

Cooperative learning in the last phase is giving rewards to groups. In the first cycle, students giving awards to groups have not increased students' interest and enthusiasm in following lessons. It is because the new students about the cooperative learning model had the class teacher had never used

\section{Cycle II reflection}

Likewise, Cycle II was also held for six meetings by applying the same learning with 
various teaching and learning processes. In the second cycle, almost none of the students were absent from attending the lesson. It is because students' curiosity about Indonesian, which was previously considered difficult, turns out to be young so that there is enthusiasm to take lessons, especially on the subject of volume building.

Likewise, the attention of students is getting more enthusiastic in receiving the subject matter. So that in doing the worksheets given are done well and smoothly even though there are still some who ask and disturb their group friends. Similarly, in giving homework, almost all students work on it and collect it even though it is done at school. In the second cycle, the enthusiasm and interest of students increased with the award given so that the motivation of students in the teaching and learning process.

\section{Student Reflection Analysis}

From the results of the analysis of students' reflections and responses, it can be concluded into the following categories:

a. Student opinion about Indonesian language lessons.

As a student, I think that Indonesian language lessons are sometimes easy to understand and sometimes difficult to understand, starting from counting to using formulas. Therefore it takes seriousness, concentration, and high discipline.

Some argue that the relative pleasure of learning Indonesian means that when the subject matter being taught is straightforward, they are happy to learn. However, if the material being taught is difficult, they are less happy to receive the subject matter.

In addition, learning Indonesian requires much practice in solving questions to improve reasoning power. By studying, humans can know many formulas and symbols. So that by studying Indonesian, all other lessons are easy to understand.

b. How is the motivation/spirit of students in learning Indonesian after using the Cooperative Learning/NHT type of cooperative learning model?

For this matter, students generally respond positively about the application of NHT cooperative learning because, with this learning model, students can learn together to complete the tasks given by the teacher so that students who feel they do not understand the material can ask students who know more. There will be an interaction between students and interactions between students and teachers with the collaboration between students.

Likewise, the awards given by teachers to students can increase students' interest and enthusiasm in participating in learning. It can be seen when the teaching and learning process occurs, where all groups compete to complete the worksheets given.

c. How should teachers teach Indonesian? 
Suggestions put forward by students on how teachers should work in Indonesian include:

1. In general, students suggest that to understand the subject matter better, examples should be given to understand better, easy to do the questions, and not easy to forget.

2. Some also suggest that presenting the material not too fast so that it is easier to understand.

\section{Conclusion}

Based on the results of data analysis and discussion, it can be concluded that:

a. NHT cooperative learning is suitable for use in this class. It can be seen from improving the learning outcomes of class VII junior high school students after the development of NHT type cooperative learning.

b. Learning outcomes obtained from the end of the cycle test, at the end of the first cycle with an average score of 40.02 from an ideal score of 100 with a standard deviation of 20.21 , while at the end of the second cycle with an average score of 68.26 from an ideal score of 100 with standard deviation 12.00 .

There was a change in student attitudes during the learning process according to the results of observations, namely the application of the NHT type cooperative learning model can increase students' confidence to ask both the teacher and their friends about material that is not understood and can increase student attendance.

\section{Iplications}

Based on the results obtained from this study, the authors propose the following suggestions:

a. To Indonesian language teachers, in particular, to try to apply the NHT type cooperative learning model in the teaching and learning process to improve student learning outcomes.

b. Indonesian teachers should be creative in creating a classroom atmosphere so that students do not get bored and tense in learning and are more motivated to pay attention to what is being taught.

c. It is better for the school to maximize suggestions and infrastructure in schools, for example, improving the quality and quantity of library books, so that students who do not have textbooks are not hampered by borrowing the library.

d. It is hoped that researchers who will conduct research should take a problem, for example, the combination of this type of NHT cooperative learning model with one of the learning 
models, to find out what its application can improve student learning outcomes

\section{REFRENCES}

Aji, H. W. (2019). Upaya Peningkatan Keaktifan dan Pemahaman Belajar Siswa pada Mata Pelajaran Bahasa Indonesia Dengan Metode Kooperatif Stad di Kelas VII D SMP Negeri 2 Ajibarang. Metafora: Jurnal Pembelajaran Bahasa Dan Sastra, 5(2), 104-115. https://doi.org/10.30595/mtf.v5i2.5077

Budiani, S., Sudarmin, S., \& Syamwil, R. (2017). Evaluasi Implementasi Kurikulum 2013 di Sekolah Pelaksana Mandiri. Innovative Journal of Curriculum and Educational Technology, 6(1), 45-57. https://doi.org/10.15294/ijcet.v6i1.15998

Esminarto, E., Sukowati, S., Suryowati, N., \& Anam, K. (2016). Implementasi Model STAD dalam Meningkatkan Hasil Belajar Siswa. Briliant: Jurnal Riset dan Konseptual, 1(1), 1623. https://doi.org/10.28926/briliant.v1i1.2

Fatimah, N. (2016). Implementasi Cooperative Learning Tipe Think-Pair-Share dalam Pembelajaran Bercerita di Sekolah Menengah Pertama. Jurnal Penelitian Humaniora, 16(2), 90-98. https://doi.org/10.23917/humaniora.v16i2.1862

Hisbullah, H. (2020). Implementasi Manajemen Pembelajaran Kurikulum 2013 di MI Darul Khaeriyah Kecamatan Suli Kabupaten Luwu. Didaktika: Jurnal Kependidikan, 9(1), 924.

Israil, I. (2019). Implementasi Model Pembelajaran Cooperative Learning Tipe STAD untuk Meningkatkan Motivasi Belajar Siswa dalam Pembelajaran IPA di SMP Negeri 1 Kayangan. Jurnal Kependidikan: Jurnal Hasil Penelitian dan Kajian Kepustakaan di Bidang Pendidikan, Pengajaran dan Pembelajaran, 5(2), 117-123. https://doi.org/10.33394/jk.v5i2.1807

Luhulima, Y. A. (2021). . Peningkatan Aktivitas dan Hasil Belajar Siswa Kelas XI melalui Penerapan Model Kooperatif Tipe Team Assisted Individualization di MA Hisbul Shuffah. Horizon Pendidikan, 15(2), 41-55.

Mirnawati, M., \& Firman, F. (2019). Penerapan Teknik Clustering Dalam Mengembangkan Kemampuan Menulis Karangan Deskripsi Siswa Kelas IV MI Pesanten Datuk Sulaiman Palopo. Jurnal Studi Guru Dan Pembelajaran, 2(2), 165-177. https://doi.org/10.30605/jsgp.2.2.2019.1373

Rakhmawati, R. (2015). Upaya meningkatkan aktivitas dan prestasi belajar matematika siswa kelas XI IPA 1 SMAN 1 Amuntai tahun pelajaran 2013/2014 melalui pembelajaran kooperatif tipe STAD. Math Didactic: Jurnal Pendidikan Matematika, 1(2), 116-123. https://doi.org/10.33654/math.v1i2.12

Sudarsana, I. K. (2018). Pengaruh Model Pembelajaran Kooperatif Terhadap Peningkatan Mutu Hasil Belajar Siswa. Jurnal Penjaminan Mutu, 4(1), 20-31. https://doi.org/10.25078/jpm.v4i1.395

Sukirman, S., \& Mirnawati, M. (2020). Pengaruh Pembelajaran Sastra Kreatif Berbasis 
Karakter Terhadap Pengembangan Karakter Siswa di Madrasah Aliyah Negeri Palopo. Didaktika: Jurnal Kependidikan, 9(4), 389-402.

Sunarya, C. (2018). Upaya Meningkatkan Hasil Belajar Matematika Materi Sistem Persamaan Linier Dua Variabel Melalui Model Cooperative Learning Tipe Student Team Achievement Division (STAD) pada Siswa Kelas VIII A SMP Negeri I Cugenang. PRISMA, 7(2), 238-246. https://doi.org/10.35194/jp.v7i2.235

Syamsuddin, A. (2019). Pembelajaran Kooperatif Tipe Numbered Head Together untuk Meningkatkan Hasil Belajar Ilmu Pengetahuan Alam. Didaktika: Jurnal Kependidikan, $8(1), 25-36$.

Wahyuni, R. (2016). Pembelajaran Kooperatif Bukan Pembelajaran Kelompok Konvensional. Jurnal Pendidikan Dasar (JUPENDAS), 3(1), Article 1. http://jfkip.umuslim.ac.id/index.php/jupendas/article/view/136

Yanti, K. D., Dr. Desak Putu Parmiti, M. S., \& Drs. Ignatius I Wayan Suwatra, M. P. (2016). Pengaruh Model Pembelajaran Kooperatif Tipe Numbered Head Together (NHT) Terhadap Hasil Belajar IPA. MIMBAR PGSD Undiksha, 4(1), Article 1. https://doi.org/10.23887/jjpgsd.v4i1.7445

Yenni, R. F. (2016). Penggunaan Metode Numbered Head Together (NHT) dalam Pembelajaran Matematika. JPPM (Jurnal Penelitian dan Pembelajaran Matematika), 9(2), Article 2. https://doi.org/10.30870/jppm.v9i2.1006 